\title{
COMPLEX THERAPY OF ACUTE POISONING BY THALLUM COMPOUNDS (Literature review and data from own research)
}

\author{
G. Balan', A. Bogomol ${ }^{2}$, O. Kravchuk', P. Zhminko', A. Kudriavtseva1 \\ 1"L.I. Medved's Research Center of Preventive Toxicology, Food and Chemical Safety, \\ Ministry of Health, Ukraine" (State Enterprise), Kyiv, Ukraine \\ ${ }^{2}$ Kyiv City Clinical Hospital of Ambulance, Kyiv, Ukraine
}

\begin{abstract}
The Aim of the Research. Based on the analysis of modern literature data and our own research to substantiate the principles of rational complex therapy with acute poisoning by thallium compounds $\left(\mathrm{Tl}^{+}\right)$at different stages of intoxication.

Materials and Methods. The analysis of literature data and our own researches is carried out and the principles of rational complex therapy with acute poisoning by thallium compounds at different stages of intoxication development are substantiated and the algorithm of doctors' actions at suspicion of acute $\mathrm{Tl}^{+}$poisoning is defined.

Results and Conclusions. The principles of complex therapy of acute $\mathrm{Tl}^{+}$poisonings substantiated, which includes antidote therapy, methods of extracorporeal treatment (plasmapheresis, hemosorption, hemodialysis), treatment of toxic encephalopolyradiculoneuropathy, neuropathic pain syndrome and toxic liver damage. The sequence of appearance of the main symptoms of intoxication at low and high doses of $\mathrm{Tl}^{+}$is determined, which allows to assume poisoning by this toxicant.
\end{abstract}

Key Words: thallium, acute poisoning, complex therapy.

Introduction. Poisoning with thallium compounds $\left(\mathrm{Tl}^{+}\right)$in Ukraine and in other countries has significantly increased compared to the previous decade [1-10]. Due to their high toxicity, these substances are banned or restricted for use in agriculture as well as in the medical field. Despite such measures, the dynamics of $\mathrm{Tl}+$ poisoning is increasing. A legitimate question arises - what is the reason? First of all, easy availability, uncontrolled possibility of purchasing thallium compounds via the Internet. This explains the increase in criminal or accidental episodes of poisoning, often group, often with fatal consequences or subsequent disability of working aged people [5-18, 20-32]. It is known that the lethal dose of $\mathrm{Tl}^{+}$ for humans is $15-20 \mathrm{mg}$ per $1 \mathrm{~kg}$ (approximately $1 \mathrm{~g}$ for humans weighing $70 \mathrm{~kg}$ ), but fatal cases of poisoning have been described at doses of 8-10 mg per $1 \mathrm{~kg}$. The half-life of $\mathrm{Tl}^{+}$ is approximately $8-30$ days, however, patients with high-dose poisoning with delayed diagnosis and late detoxification therapy, elevated $\mathrm{Tl}^{+}$ levels in the bioenvironment (blood, urine, hair, nails) are detected after 1.5-2 months [1-14, 20-32]. The intensive therapy with the inclusion of antidotes, forced diuresis and intestinal lavage, the half-life of thallium is reduced to a few days. In the previous issue of the journal our article "Acute oral and inhalation thallium poisoning and their long-term consequences" [5] summarizes modern ideas about the pathogenesis the major clinical syndromes formation of acute $\mathrm{Tl}^{+}$poisoning and features of syndromology in acute and in the late period intoxication. Of particular interest is the generalization of current literature data and own observations on the principles of rational comprehensive treatment of patients with acute $\mathrm{Tl}^{+}$poisoning with the inclusion of antidotes, detoxification methods, using enterosorbents and in vitro therapy for early and delayed diagnosis. The principles of toxic encephalopolyradiculoneuropathy treatment, especially neuropathic pain, as well as toxic liver and kidney damage, need to be clarified.

The Aim of the Research. Based on the analysis of modern literature data and our own research to substantiate the principles of rational complex therapy with acute poisoning by thallium compounds $\left(\mathrm{Tl}^{+}\right)$at different stages of intoxication.

Materials and Methods. The scientific analysis of modern literature data and our own researches is carried out. The principles of rational complex therapy of acute poisoning 
with thallium compounds at different stages of intoxication are substantiated. The analytical review of scientific publications was performed using abstract databases of scientific libraries Pub Med, Medline and text databases of scientific publishers Elsevier, Pub Med Central and other VIP-databases. Methods of system, comparative and content analysis are used.

Results and Discussion. One of the basic principles of $\mathrm{Tl}^{+}$toxicity is based on the fact that its ionic radius is similar to the ionic radius of potassium $(\mathrm{TL}-0.147 \mathrm{~nm}$, potassium $0.133 \mathrm{~nm}$ ), so it accumulates in tissues with high concentrations of potassium, such as central and peripheral nervous system, muscles, and heart [16]. $\mathrm{Tl}^{+}$inhibits potassium-dependent processes by inhibiting a number of enzymes, including pyruvate kinase and succinate dehydrogenase, which is accompanied by inhibition of glucose metabolism and dysfunction of the Krebs cycle with decreased ATP synthesis, inhibition of tissue respiration and the formation of energy deficiency. This is facilitated by a decrease in the activity of $\mathrm{Na}^{+} / \mathrm{K}^{+}$-ATPase. In turn, enzymatic disorders lead to damage to cell membranes, swelling and vacuolation of mitochondria and cell death - activation of apoptosis. The thallium has tropism to disulfide bonds, which is accompanied by inhibition of SH-groups and disrupts the synthesis of SH-containing components - cysteine, keratin, antioxidant glutathione, which leads to activation of lipid peroxidation in tissues, especially in brain structures (mostly in the cerebellum) $[12,14] . \mathrm{Tl}^{+}$ also inhibits the synthesis of riboflavin and flavin-coenzyme - flavinadenonucleotide (FAD), which disrupts the electron transfer chain and synaptic connections [12, 14]. This is also facilitated by excessive activation of NMDA receptors - a glutamatergic component of $\mathrm{Tl}^{+}$-induced toxicity, which causes excessive excitability of nerve cells.

$\mathrm{Tl}^{+}$poisoning is uncommon, so it is usually not diagnosed in time until it is confirmed by increased levels of thallium in the environment (urine, blood, feces, hair, nails). The clinical manifestations of $\mathrm{Tl}^{+}$poisoning in the first days are quite nonspecific, but the combination of a number of symptoms and the sequence of their development should make a doctor suspect acute $\mathrm{Tl}^{+}$poisoning and begin chemical and toxicological examination.

In the first hours of $\mathrm{Tl}^{+}$poisoning, gastrointestinal disorders are most often observed, accompanied by intense abdominal pain, often intestinal colic, as in lead intoxication, nausea, vomiting, diarrhea, anorexia, which mimics the picture of food poisoning, constipation and flatulence are less common. However, it should be noted that these gastrointestinal disorders precede or combine with painful paresthesias in the toes and feet, intense stabbing pains in the soles of the feet, convulsions, increasing tremor, at high doses - mental disorders, sleep disorders, headaches, cerebral nerves damage with a decrease in corneal and pharyngeal reflexes, as well as an increase in body temperature to $37.6-38^{\circ} \mathrm{C}$; in addition, on the first day, especially with large doses, urine becomes greenish [1-15, 31, 43].

On the $2^{\text {nd }}-10^{\text {th }}$ day, neurological disorders progress, tremor increases, ataxia, pain in the extremities increases, especially in the calf muscles and muscles of the inner thigh, becoming neuropathic, there are muscle atrophies, mostly in the upper shoulder girdle, legs and thighs, increasing disorders of the cranial nerves, possible facial nerve palsy, ptosis, diplopia, retrobulbar neuritis, visual impairment. If in the first 2-3 days tendon reflexes remain, then later they disappear, at high doses appear flaccid paralysis, tetraparesis, disorders of the pelvic organs, as well as join the dysfunction of the heart, kidneys, often death from cardiovascular insufficiency $[1-15,26$, 31-37, 43].

After 7-14 days, the survived patients have alopecia, mainly in the parietal and temporal areas of the head (Fig. 1), also hair disappears in the axillary and pubic areas, medial and lateral thirds of the eyebrows, skin becomes cracked, as well as there can be hyperkeratosis of the palms and soles, cracks in the corners of the mouth, brown pigmentation, dark pigment deposits on the skin around the hair follicles, developing pyoderma (pustular rashes and small boils, especially on the face, rarely on the chest and back, back), nail growth sharply decreases, there is their dullness, yellowish tinge, horizontal tortuosity with the appearance of white transverse stripes (Mees stripes, Fig. 2) $[3-16,22,25,31,33,35]$. It is the sequence and combination of the described gastrointestinal and neurological disorders, especially the appearance of alopecia and specific skin lesions, that obliges the doctor to suspect $\mathrm{Tl}^{+}$poisoning and to prescribe a chemical-toxicological examination and consultation with a toxicologist. 


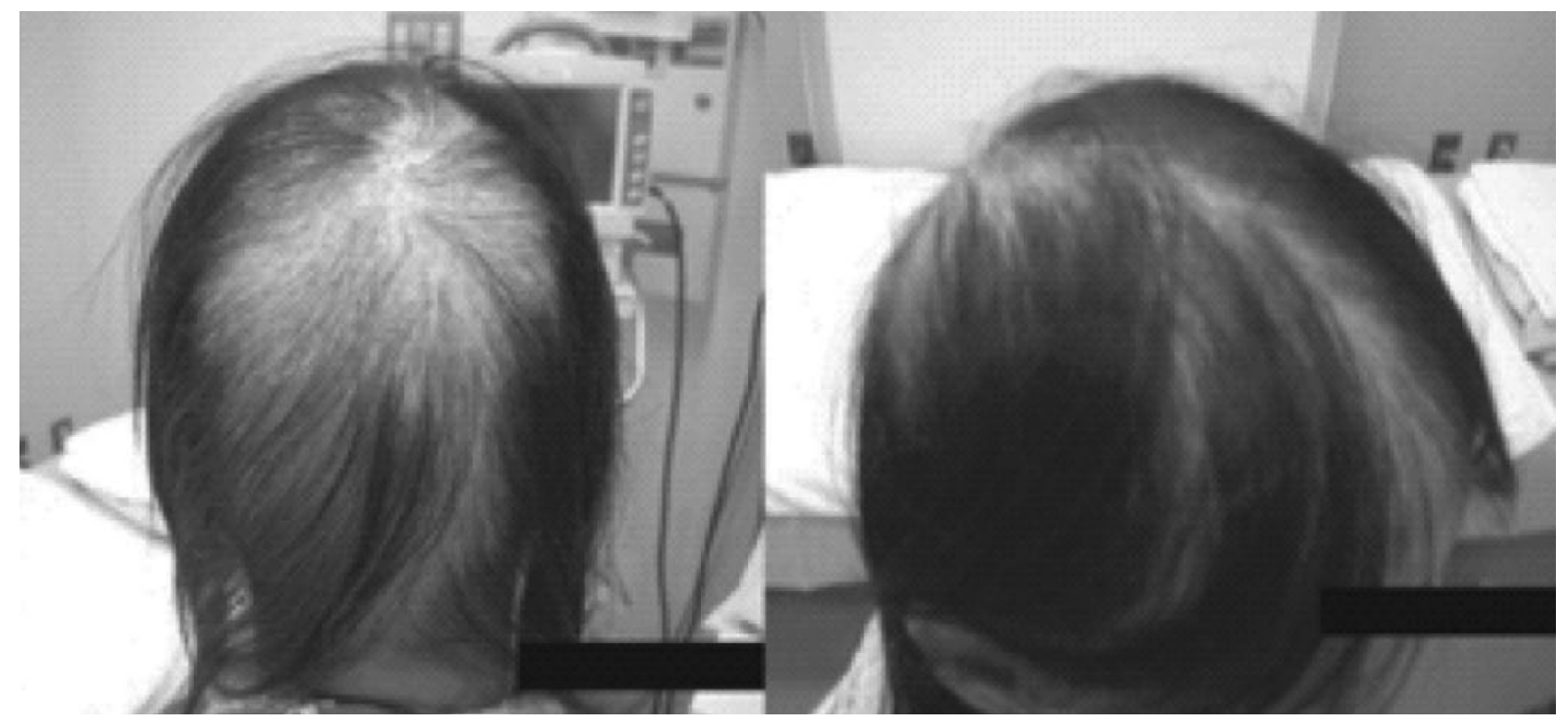

Fig. 1. Alopecia of the scalp in patients with acute thallium poisoning (Yomoto T. et al, 2017) [1].

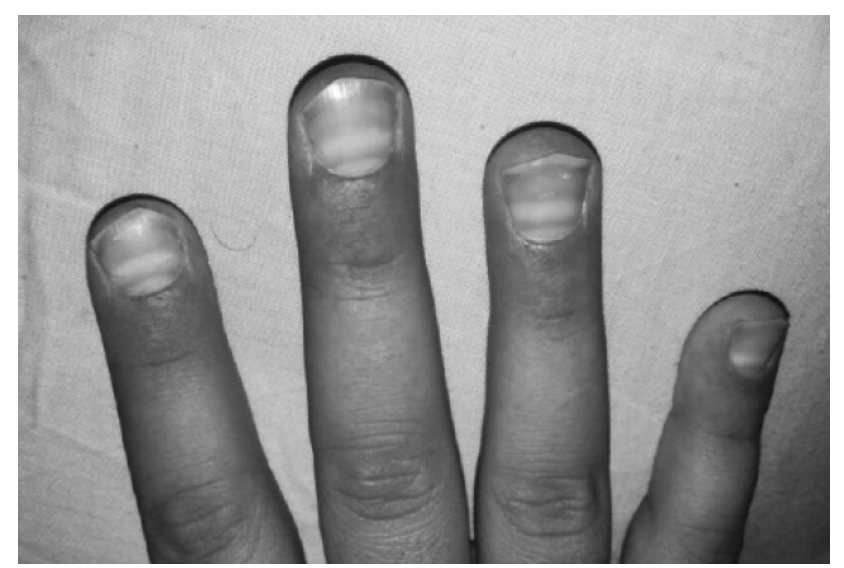

Fig. 2. Nail lesions with the formation of transverse Meesstripes in a patient with acute thallium poisoning (Almassri I., Sekkarie M., 2018) [6].

The analysis of literature data and own experience of treatment of 6 patients with acute $\mathrm{Tl}^{+}$poisoning [5] shows that treatment of intoxications with this toxicant should be aimed primarily at removing waist from the body: in early hospitalization - gastrointestinal lavage with enterosorbents (activated charcoal, $\mathrm{C}$ carbolong, $\mathrm{KAU}$, etc.), intestinal lavage or enema with hypertonic solution, as well as the appointment of sorbitol $25 \mathrm{~g} \mathrm{3-4} \mathrm{times} \mathrm{a} \mathrm{day} \mathrm{to}$ cause hyperosmolar diarrhea, forced diuresis with mandatory monitoring of potassium and sodium levels in blood plasma. At the same time, potassium iron hexacyanoferrate (ferrocin, Berlin azure, Prussian blue) is used as antidote therapy. It is the most effective in the first $1-3$ days $[12,18,19,29,34,35,42]$. By the way, its positive effect has been proven in the later diagnosis of $\mathrm{Tl}^{+}$poisoning (even for 1.52.5 months), as it promotes accelerated excretion from the body [1-18, 20-29, 34-43]. Ferrocin prescribed simultaneously with the strengthening of natural detoxification in adults and children over 14 years -1 g 36 times per day (depending on the dose and the content of thallium in the bioenvironment, especially in the daily urine); children older than 2 years $-0,5 \mathrm{~g} 3$ times per day to control the excretion of thallium (to its level in the urine - below $100 \mu \mathrm{g} / \mathrm{l}$ ). Ferrocin powder for suspension is dissolved in $100 \mathrm{ml}$ of water or $10 \%$ mannitol solution.

In the treatment of 17 patients (adults and children) who fell ill in Syria after eating poisoned $\mathrm{Tl}^{+}$sweets, the diagnosis was clarified only after 40 days [6]. The content of thallium in the semen of men at this time was 700$800 \mu \mathrm{g} / \mathrm{l}$. Prescribing hemodialysis at late stage of intoxication was not effective. The use of Prussian blue at a dose of $1500 \mathrm{mg} 3$ times a day for 18 days contributed to the normalization of thallium levels in the bioenvironment, but neurological disorders decreased only after 1.5-2 years [6]. In 8 patients who were poisoned after a voluntary intravenous infusion of thallium sulfate, with its content in the urine 25000$40000 \mu \mathrm{g} / 1$, the use of Prussian blue in three cases was not effective (patients died), and five survived with normalization of thallium levels in urine after a month and partial regression of neurological disorders in 2-4 years [7].

H.A. Livanov et al. [8] described 44 patients with acute $\mathrm{Tl}^{+}$poisoning were detected 3.5 
months after the onset of gastrointestinal, neurological and psycho-emotional disorders. In 7 patients after 3.5 months, the content of thallium in blood plasma was $8.3-26.7 \mu \mathrm{g} / \mathrm{l}$, in urine - 48.7-356.1 $\mu \mathrm{g} / 1$, their condition was considered moderate. In 23 patients, the level of thallium in the blood was $0.33-6.11 \mu \mathrm{g} / \mathrm{l}$, in urine $-2.8-68.48 \mu \mathrm{g} / 1$ - poisoning was defined as mild. The use of ferrocin for $1-$ 20 days contributed to the normalization of thallium levels in bioenvironment and regression of neurological disorders, which indicates that $\mathrm{Tl}^{+}$in bioenvironment after poisoning can be determined in 3.5 months, and the antidote ferrocinis effective in such a delayed period.

Later in his publications H.A. Livanov et al. [11] also note the effectiveness of ferrocin in the early stages of $\mathrm{Tl}^{+}$intoxication. It is recommended to include oral administration of 3$5 \%$ sodium iodide solution in the composition of antidote therapy, which promotes the formation of insoluble iodine compounds $\mathrm{Tl}$ and slows its absorption in the intestine. The authors also recommend the use of donor $\mathrm{SH}-$ groups of unithiol in the form of $5 \%$ solution intramuscularly or intravenously and 2.5$3.0 \mathrm{ml}$ of potassium chloride in the form of 4 or $10 \%$ solution intravenously during the day, although most authors note an increase in symptoms of toxic lesions of the central nervous system when prescribing potassium $[1,9$, $16,26,31,32]$. In severe cases, the authors recommend hemodialysis, which significantly accelerates the purification of the body from $\mathrm{Tl}^{+}$and a significant reduction in clinical manifestations of poisoning. The authors note that to achieve the proper clinical and laboratory effect, it may take an extremely long 120200 hours for 7-10 days. The clearance of $\mathrm{Tl}$ excreted from the body varies from 13 to $339 \mathrm{mg}$, while in the process of forced diuresis - from 9 to $159 \mathrm{mg}$, which is $1.5-2$ times less than during hemodialysis. The authors note a certain detoxification effect when using hemosorption, in the process of which the clearance of $\mathrm{Tl}^{+}$reached $72-133 \mathrm{ml} / \mathrm{min}$ (at the level of clearance during forced diuresis). In severe $\mathrm{Tl}^{+}$poisoning, the authors recommend plasmapheresis.

L.V. Zavaliy et al. [13] describe the features of neurological disorders in patients with $\mathrm{Tl}^{+}$ poisoning (44 victims patients), with the assumption of a criminal oral route of exposure to the toxicant (with drinking water from an office cooler). Of the 44 victims who were hospitalized in N.V. Sklifosovsky Research Institute of Ambulance with suspected $\mathrm{Tl}^{+}$ poisoning 69 days after the onset of neurological disorders and alopecia, 30 patients showed elevated levels of thallium in the environment: in 7 - the level of thallium in the blood was $13.7 \mu \mathrm{g} / 1$ and $95.64 \mu \mathrm{g} / 1$ in urine , in $21-$ in urine $17,39 \mathrm{mkg} / \mathrm{l}$, and in $2-$ in blood 24,05 and $19,4 \mathrm{mkg} / \mathrm{l}$, in urine $-356,1$ and $102,9 \mathrm{mkg} / \mathrm{l}$. These data suggest once again that without antidote therapy, even after 2 or more months, the level of thallium in the bioenvironment may be elevated, which normalized after the use of ferrocin and symptomatic therapy. The authors note that pain, motor and coordination disorders regress in the first place, and sensitive, cognitive and emotional disorders persist for a long time; polyneuropathy gradually transforms into mononeuropathy, and tremor may even increase.

Of particular interest is the effectiveness evaluation of extracorporeal treatment methods of $\mathrm{Tl}^{+}$poisoning, both alone and in combination with the antidote therapy. Thus, a number of studies have described the combined use of the antidote Prussian blue (ferrocin) and plasmapheresis $[12,15,37,38,39,41]$. In the research [15] a case of $\mathrm{Tl}^{+}$poisoning was described about a 42-year-old woman who suddenly developed abdominal and limb pain, followed by severe neurological disorders and coma. Only on day $35, \mathrm{Tl}^{+}$poisoning was suspected, its concentrations in blood and urine were 950 and $7600 \mathrm{ng} / \mathrm{ml}$. Accordingly, the patient was on mechanical ventilation, biochemical examination revealed an increase in ALT to 55 units and a decrease in albumin levels to $30 \mathrm{~g} / 1$, indicating that in addition to toxic encephalopolyneuropathy and cardiopulmonary insufficiency, she also had liver damage. The patient received Prussian blue at $6600 \mathrm{mg}$ per day and symptomatic therapy (neuro-, gastro-, hepatoprotective drugs, B vitamins etc.). On day 45, the thallium content in blood and urine was 380.0 and $2580.0 \mathrm{ng} / \mathrm{ml}$, respectively. She underwent 5 sessions of plasmapheresis, after which she came out of a coma, waist content returned to normal, but there were signs of neuropathy, cognitive impairment and lower paraparesis, which persisted for 37 months. Thus, the late appointment of Prussian blue and plasmapheresis improved the patient's condition, normalized the content of thallium 
in biological media, but did not contribute to the regression of severe neurological disorders; preserved cognitive impairment and paresis of the lower extremities and after 3 years. However, the effectiveness of extracorporeal methods of treatment of $\mathrm{Tl}^{+}$poisoning in the early stages of intoxication is confirmed by a number of authors, although the unanimous opinion of experts on the effectiveness of accelerated excretion methods adopted in metal poisoning: hemodialysis, hemosorption and plasmapheresis and unithiol does not exist $[8,11,16,31]$. Most researchers recommend the use of extracorporeal therapy only in the early periods of $\mathrm{Tl}^{+}$poisoning $[8,11,15,28,37$, $38,39]$. The effectiveness of chelating agents, in particular EDTA, dimercaprol and D-penicillamine, has also not been proven - data on the effectiveness of these drugs in $\mathrm{Tl}^{+}$poisoning are very contradictory [16, 40, 42, 44, 45]. No efficacy was found in reducing mortality in animal models in $\mathrm{Tl}^{+}$and $\mathrm{N}^{-}$acetylcysteine and L-cysteine intoxication [16].

The effectiveness of treatment of 6 patients with delayed diagnosis of acute $\mathrm{Tl}^{+}$poisoning, which we observed in recent years [5], depended on both the severity and duration of antidote therapy. In 3 cases of severe oral $\mathrm{Tl}^{+}$poisoning (two of them - criminal nature and one - due to accidental use of a solution of thallium sulfate, allegedly prepared for deratization), the disease began with nausea, vomiting, abdominal pain, fever, intense muscle pain in limbs, especially in the legs and soles of the feet, a week later all three began hair loss, after 2 weeks - diffuse alopecia, mainly in the parieto-occipital region, as well as facial pyoderma, cracks in the corners of the mouth, hyperkeratosis in the hands and feet, sensitive and motor neurological disorders in the upper and lower extremities, as well as dysarthria, ataxia, tremor, then flaccid paresis of the lower extremities with the disappearance of tendon reflexes, decreased visual acuity. In all three cases, there was a pronounced malnutrition of the muscles of the legs, thighs, forearms and shoulders, pelvic dysfunction. In two patients, $\mathrm{Tl}^{+}$poisoning was suspected two weeks later (after the onset of alopecia). At this time, the thallium content in their urine was 2840 and $2160 \mu \mathrm{g} / 1$, respectively. The third patient was diagnosed with $\mathrm{Tl}^{+}$poisoning only a month later, and the thallium content in his urine was $1,425 \mu \mathrm{g} / 1$. All three patients after diagnosis of
$\mathrm{Tl}^{+}$poisoning took ferrocin $1 \mathrm{~g}$ 3-6 times a day, the first two received 6 sessions of hemodialysis and symptomatic therapy, the level of thallium in their urine returned to normal in 2030 days, but as soon as after treatment, and after 3 years there is a pronounced flaccid paresis of the lower extremities, impaired vision and speech. It should be noted that the third patient before the diagnosis of $\mathrm{Tl}^{+}$poisoning received 6 sessions of plasmapheresis, and began antidote therapy with ferrocin only a month later (the content of thallium in his urine was $1425 \mu \mathrm{g} / \mathrm{l})$. Given that all three patients had intense neuropathic pain, especially in the lower extremities, they received gabapentin (900 mg/day) and venlafaxine (150 $\mathrm{mg}$ /day) for 2-3 weeks, as well as intravenous infusions of the antioxidant a-lipoic acid (600 $\mathrm{mg} /$ day), B vitamins, hepatoprotective drugs, neuroprotectors (citicoline, oxybral, etc.), as well as symptomatic therapy. The patient suffered from severe encephalo- polyneuropathy with flaccid paresis of the lower extremities, but he had a more noticeable regression of neurological disorders - a year later he began to move independently with crutches, although he continued flaccid paresis of the lower extremities. It cannot be ruled out that a more noticeable regression of neurological disorders in this patient was due not only to antidote therapy a month after poisoning, but also to 6 sessions of plasmapheresis in the early stages of the disease, when he was treated in the neurology department with a diagnosis of polyneuropathy of unknown etiology.

In addition, there were three patients with accidental inhalation poisoning with thallium sulfate. The causes of poisoning and the development of clinical manifestations in these patients are described in detail in the previous issue of this journal [5]. The first patient with a delayed diagnosis - severe $\mathrm{Tl}^{+}$poisoning died of progressive pulmonary vascular insufficiency. Two other patients were treated for a month for acute inhalation poisoning $\mathrm{Tl}^{+}$with encephalopolyneuropathy II-III degree and toxic hepatitis I-II degree of severity in the $2^{\text {nd }}$ patient and with encephalopolyneuropathy II degree of severity and toxic hepatitis I-IIdegree of severity in the 3rd patient In both patients, a week after the onset of the disease, the level of thallium in the hair was more than 10 times higher than normal, and in the urine 280.0 and $320.0 \mu \mathrm{g} / 1$, respectively. They 


\section{ORIGINAL RESEARCH}

CLINICAL TOXICOLOGY

received ferrocin $1.0 \mathrm{~g} 3$ times a day, intravenous infusions of $\alpha$-lipoic acid, hepatoprotective drugs, gabapentinum, citicoline, B vitamins for a month before normalization of thallium levels in the urine. After treatment pain and paresthesia in the extremities, headache, convulsions decreased. Despite the regression of neurological disorders and normalization of thallium levels in urine, chemical and toxicological analysis in a second patient with more pronounced neurological disorders revealed a thallium level in hair $3980 \mu \mathrm{g} / \mathrm{kg}$, in nails $-9080 \mu \mathrm{g} / \mathrm{kg}$ and in skin epithelium - $620 \mu \mathrm{g} / \mathrm{kg}$, and in the third patient in the hair $-800 \mu \mathrm{g} / \mathrm{kg}$, in the nails $2230 \mu \mathrm{g} / \mathrm{kg}$ and in the skin epithelium $190 \mu \mathrm{g} / \mathrm{kg}$. This indicates that in the hair, nails and skin epithelium, elevated waist levels last much longer than in blood and urine, despite antidote therapy.
Conclusions. Thus, complex therapy of patients with acute $\mathrm{Tl}^{+}$poisoning should include antidote therapy with ferrocin (Prussian blue, Berlin azure) to normalize $\mathrm{Tl}^{+}$ levels in blood and urine in combination with extracorporeal detoxification methods, which are more effective in early periods of intoxication, and neuro- and hepatoprotective drugs, vitamins $\mathrm{B}$ etc. For the treatment of neuropathic pain in the extremities, it is advisable to prescribe gabapentinum and venlafaxine hydrochloride. Unfortunately, in severe forms of $\mathrm{Tl}^{+}$poisoning persistent neurological disorders with paresis of the lower extremities, impaired vision and speech (with permanent disability), which indicates the need to develop new more effective methods of detoxification and rehabilitation of patients with these intoxications.

The autors declare that there are no conflicts of interest

\section{REFERENCES}

1. Yumoto T, Tsukahara K, Naito H, Iida A, Nakao A. A Successfully Treated Case of Criminal Thallium Poisoning. J Clin Diagn Res. 2017 Apr; 11 (4): OD01-OD02.

2. Pelclova D, Urban P, Ridzon P, Senholdova Z, Lukas E, Dibiik $P$ et al. Two year follow up of two patients after severe thallium intoxication. Hum Exp Toxicol. 2009; 28(5): 263-72.

3. Al Hammouri F, Darwazeh G, Said A, Ghosh RA. Acute thallium poisoning: series of ten cases. J Med Toxicol. 2011 Dec; 7(4): 306-11.

4. Centers for Disease Control and Prevention (CDC) Thallium poisoning from eating contaminated cake - Iraq, 2008. MMWR Morb Mortal Wkly Rep. 2008; 57: 1015-8.

5. Balan HM, Bohomol AH, Zhminko PH, Bubalo NM, Bubalo VO, Kudriavtseva AH, Babych VA, Mymrenko TV. Acute oral and inhalation thallium poisoning and their long-term consequences. 2020; 1: 79-90.

6. Almassri I, Sekkarie M. Cases of thallium intoxication in Syria: A diagnostic and a therapeutic challenge. Avicenna J Med. 2018 Jul-Sep; 8(3): 78-81.

7. Di Candia D, Muccino E, Battistini A, Boracchi M, Gentile G, Zoja R. Thallium toxicity due to adulterer infusion with thallium sulfate in eight members belonging to the same family nucleus: Autopsy findings and ICP-MS analysis (inductively coupled plasma mass spectrometry) in a triple homicide. Leg Med (Tokyo). 2020 Feb; 42: 101661.

8. Livanov GA, Shestova GV, Sukhodolova GN, Batotsyrenov $\mathrm{BV}$ et al. Clinic, diagnosis and treatment of acute severe poisoning with thallium compounds. Emergency. 2019; 3: 9-15.

9. Riyaz R, Pandalai SL, Schwartz M, Kazzi ZN. A fatal case of thallium toxicity: challenges in management. J. Med. Toxicol. 2013; 9(1): 75-80.

10. Sojakova M, Zigrai M, Karaman A, Plackova S, Klepancova P, Hrusovsky S. Thallium intoxication. Case Report. Neuro Endocrinol. Lett. 2015; 36(4): 311-31.
11. Livanov GA. Early diagnosis and treatment of acute poisoning with thallium compounds. General resuscitation. 2013; 3: 35-40.

12. Osorio-Rico L, Santamaria A, Galván-Arzate S. Thallium Toxicity: General Issues, Neurological Symptoms, and Neurotoxic Mechanisms. Adv Neurobiol. 2017; 18: 345-53.

13. Zavaliy LB, Petrikov SS, Simonova AYu, Potsveriya MM, OstapenkoYuN. Characteristics of neurological disorders in patients with acute thallium poisoning. Consilium Medicum. 2019; 21(2): 24-30.

14. Yu V, Juhász M, Chiang A, Atanaskova-Mesinkovska N. Alopecia and Associated Toxic Agents: A Systematic Review. Skin Appendage Disord. 2018 Oct; 4(4): 245-60.

15. Guodong Lin, Luo Yuan, Lili Bai, Yanging Liu, Yongan Wang, Zewu Qiu. Successful treatment of a patient with severe thallium poisoning in a coma using Prussian blue and plasma exchange. Medicine. 2019; 98: 8

16. Gresham C, Vearrier D. Thallium Toxicity. Medscape. com. Updated: Feb. 19. 2018.

17. Chupovina ML. Medical andhygienic aspects of thallium neurotoxity. Hygiene and sanitation. 1999; 4: 38-40.

18. Sun TW, Xu QY, Zhang XJ, Wu Q, Liu ZS, Kan QC, Sun CY, Wang L. Management of thallium poisoning in patients with delayed hospital admission. Clin. toxicol. 2012; 50: 65-9.

19. Jiang Y, Xia W, Zhang B, Pan X, Liu W, Jin S, Huo W, Liu H, Peng Y, Sun X, Zhang H, Zhou A, Xu S, Li Y. Predictors of thallium exposure and its relation with preterm birth. Environ Pollut. 2018 Feb; 233: 971-6.

20. Misra UK, Kalita J, Yadav, Ranjan P. Thallium poisoning: emphasis on early diagnosis and response to haemodialysis. Postgrad Med. J. first published.2003; 2: 48-50.

21. Kuroda H, Mukai Y, Nishiyama S, Takeshita T, Takeshita T, Tateyama M, Takeda A, Aoki M. Tardily accelerated neurologic deterioration in two-step thallium intoxication. J. Clin Neurosci. 2016 Dec; 34: 234-6. 


\section{ORIGINAL RESEARCH \\ CLINICAL TOXICOLOGY}

22. Livanov GA, Ostapenko YuN, Shestova GV et al. The importance of early diagnosis of acute severe poisoning with thallium compounds at the initial stages of intoxication. Toxicologybulletin. 2011; 5: 1-8.

23. Shablina LP, Kirilov VF, Spiridonova VS, Poliakova MM et al. Methods for the diagnosis of thallium intoxication and antidote therapy for thallium toxicosis. Occupational medicine and industrial ecology. 1996; 10: 25-30.

24. Locatelli C, Petrolini V. Long-lasting polyneuropathy and psychiatric disorders in thallium poisoning. Study of six cases. Toxicology Letters. 2003; 1. 144. Supplement 1: 724.

25. Moore D, House I. Thallium poisoning. Diagnosis may de elusive but alopecia is the clue. BMJ. 1993; 306: 1527-9.

26. Wainwroght AP, Kux WJ, House IM et al. Clinical features and therapy of acute thallium poisoning. Q J Med 1988; 69: 939-44.

27. Dumitru D, Kalantri A. Electrophysiologic investigation of thallium poisoning. Muscle Nerve. 1990; 13: 433-7.

28. Nogue S, Mas A, Pares A et al. Acute thallium poisoning: an evaluation of different forms of treatment. J. Toxicol. Clin. Toxicol. 1982; 19: 1051-21.

29. Hoffman RS, Shringer JA, Feinberg RS et al. Comparative efficacy of thallium adsorption by activated charcoal Prussian blue and sodium polystyrene sulfonate. J. Toxicol. Clin. Toxicol. 1999; 37: 833-7.

30. Chip Gresham. Thallium toxicity treatment \&management. Medscape. 2018; 2.

31. Potshveriya MM, Ostapenko YuN, Petrikov SS, Simonova AYu, Zavaliy LB, Ilyashenko KK, Dikaya TI, Gayduk MV. Massive poisoning. Russian Sklifosovsky Journal of Emergency Medical Care. 2019; 8(3): 332-336.

32. Lech T, Sadlik JK. Thallium intoxication in humans. Toxicol. Lett. 2007; 172: 85.

33. Yang G, Li C, Long Y et al. Hair loss evidence to thallium poisoning. Case Rep Emerg Med. 2018.
34. Shcherbak ST, Belskich AN, Safana AM. The clinical picture and modern therapy of acute thallium poisoning. Medical consequences of extreme effects on the body. SPb. 2000; 54-8.

35. Zavaliy LB, Simonova AYu, Potshveriya MM, Ostapenko YuN et al. Diagnostics and treatment for thallium poisoning. Toxicology bulletin. 2018; 5: 9-15.

36. Yu-Tai Tsai, Chin-Chang Huang et al. Central nervous system effects in acute thallium poisoning. Neuro Noxicjlogy. 2006; 27: 291-5.

37. Ghannoum M, Nolin TD, Goldfarb DS, Roberts DM, Mactier R, Mowry JB et al. Extracorporeal treatment for thallium poisoning: Recommendations from the EXTRIP workgroup. Clin j Am Soc Nephrol. 2012; 7: 1682-90.

38. Tian YR, Sun LI, Wang W et al. A case of acute thallotoxicosis successfully treated with double-filtration plasmapheresis. Clin Neuropharmacol. 2005; 28: 292-4.

39. Schutt RC, Ronco C, Rosner MN. The role of therapeutic plasma exchange in poisonings and intoxications. Semin Dial. 2012; 25: 201-6.

40. Fedotov IA. The influence of chelators on the treatment for severe poisoning with thxallium salts: Abstract for the dissertation of the candidate of medical sciences. SPb. 2008. $21 \mathrm{p}$.

41. Hoffman RS. Thallium toxicity and the role of Prussian blue in therapy. Toxicol. Revt. 2003; 22: 29-40.

42. Pau PWI. Management of thallium poisoning. HKMJ. 2000; 6(3): 316-8.

43. Sha S, Kumar R. Thallium poisoning. Presenting as Paresthesias, Paresis, Psychosis and Pain in Abdomen. JAPI. 2006; 54: 53-55.

44. Huang C, Zhang X, Li G et al. A case of severe thallium poisoningsuccessfully treated with hemoperfusion and continuous veno-venous hemofiltration. Hum. Exp. Toxicol. 2014; 33: 554-8.

\section{КОМПЛЕКСНА ТЕРАПІЯ ГОСТРИХ ОТРУЕНЬ СПОЛУКАМИ ТАЛІЮ}

(Огляд літератури та дані власних досліджень)

Г.М. Балан ${ }^{1}$, А.Г. Богомол², О.П. Кравчук ${ }^{1}$, П.Г. Жмінько ${ }^{1}$, А.Г. Кудрявцева ${ }^{1}$

${ }^{1}$ ДП «Науковий центр превентивної токсикології, харчової та хімічної безпеки імені академіка Л.І. Медведя

Міністерства охорони здоров'я України», м. Київ, Україна

${ }^{2}$ Київька міська клінічна лікарня швидкої медичної допомоги, м. Київ, Україна

PЕЗЮМЕ. Мета роботи. На основі аналізу сучасних літературних даних і власних досліджень обгрунтувати принципи раціональної комплексної терапії хворих з гострими отруєннями сполуками талію $\left(\mathrm{Tl}^{+}\right)$на різних етапах інтоксикації. Матеріали і методи. Проведено науковий аналіз даних літератури і власних досліджень та обгрунтовано принципи раціональної комплексної терапії хворих з гострими отруєннями сполуками талію на різних етапах розвитку інтоксикації та визначено алгоритм дії лікаря при підозрі на гостре отруєння $\mathrm{Tl}^{+}$.

Результати та висновки. Обгрунтовано принципи комплексної терапії гострих отруєнь $\mathrm{Tl}^{+}$, яка включає антидотну терапію, методи екстракорпорального лікування (плазмаферез, гемосорбцію, гемодіаліз), лікування токсичної енцефалополірадикулоневропатії, нейропатичного больового синдрому та токсичного ураження печінки і нирок при ранньому і відтермінованому встановленні діагнозу. Визначено послідовність появи основних симптомів інтоксикації за низьких і високих доз $\mathrm{Tl}^{+}$, що дозволяє припустити отруєння даним токсикантом.

Ключові слова: талій, гострі отруєння, комплексна терапія. 


\section{ORIGINAL RESEARCH \\ CLINICAL TOXICOLOGY}

\section{КОМПЛЕКСНАЯ ТЕРАПИЯ ОСТРЫХ ОТРАВЛЕНИЙ СОЕДИНЕНИЯМИ ТАЛЛИЯ}

(Обзор литературы и данные собственных исследований)

Г.М. Балан ${ }^{1}$, А.Г. Богомол ${ }^{2}$, А.П. Кравиук ${ }^{1}$, П.Г. Жминько ${ }^{1}$, А.Г. Кудрявиева ${ }^{1}$

${ }^{1}$ ГП «Научный центр превентивной токсикологии, пищевой и химической безопасности имени академика Л.И. Медведя Министерства здравоохранения Украины», г. Киев, Украина.

${ }^{2}$ Киевская городская клиническая больница скорой медицинской помощи, г. Киев, Украина.

PЕЗЮМЕ. Цель работы. На основе анализа современных литературных данных и собственных исследований обосновать принципы рациональной комплексной терапии больных с острыми отравлениями соединениями таллия $\left(\mathrm{Tl}^{+}\right)$на разных этапах интоксикации.

Материалы и методы. Проведен научный анализ данных литературы и собственных исследований и обоснованы принципы рациональной комплексной терапии больных с острыми отравлениями соединениями таллия на разных этапах развития интоксикации и определен алгоритм действий врача при подозрении на острое отравление $\mathrm{Tl}^{+}$.

Результаты и выводы. Обоснованы принципы комплексной терапии острых отравлений $\mathrm{Tl}^{+}$, которая включает антидотную терапию, методы экстракорпорального лечения (плазмаферез, гемосорбиию, гемодиализ), лечение токсической энцефалополирадикулоневропатии, нейропатического болевого синдрома и токсического поражкения печени и почек при раннем и отсроченном установлении диагноза. Определена последовательность появления основных симптомов интоксикации при низких и высоких дозах $\mathrm{Tl}^{+}$, что позволяет предположить отравление данным токсикантом.

Ключевые слова: таллий, острые отравления, комплексная терапия.

Received 07/03/2020 